\title{
A comparison of the cost of generic and branded food products in Australian supermarkets
}

\author{
Kathryn Chapman ${ }^{1, *}$, Christine Innes-Hughes ${ }^{1}$, David Goldsbury ${ }^{1}$, Bridget Kelly ${ }^{2}$, \\ Adrian Bauman ${ }^{2}$ and Margaret Allman-Farinelli ${ }^{3}$ \\ ${ }^{1}$ Cancer Council NSW, 153 Dowling Street, Woolloomooloo, Sydney, NSW 2011, Australia: \\ ${ }^{2}$ Prevention Research Collaboration, School of Public Health, University of Sydney, Sydney, Australia: \\ ${ }^{3}$ School of Molecular and Microbial Biosciences, University of Sydney, Sydney, Australia
}

Submitted 28 August 2011: Final revision received 19 February 2012: Accepted 28 February 2012: First published online 4 April 2012

\begin{abstract}
Objective: Food cost is an important factor influencing the consumption of nutritious foods and subsequent chronic disease risk. The present study compared the cost of branded food products with their generic equivalents across a range of food categories.

Setting: The survey was conducted within two major supermarket chains across six locations in Sydney, Australia ( $n$ 12).

Design: Price differences were calculated for 'core' (nutrient dense and low in energy) and 'extra' (high in undesirable nutrients and/or energy) packaged foods ( $n$ 22) between generic and branded items.

Results: A cost saving of $44 \%$ was found by purchasing generic over branded products across all food categories. The most significant savings were for core foods, such as bread and cereals, and the smallest cost savings were seen for fruit products. There was little variation in cost saving between branded and generic products by socio-economic status of the supermarket location.

Conclusions: The large price differential between branded and generic food products implies that consumers, particularly those on lower incomes, could benefit financially from purchasing generic items. The promotion of core generic products may be an effective strategy to assist people on lower incomes to meet dietary guidelines.
\end{abstract}

Keywords
Food costs
Generic
Nutrition

Generic food brands are those that are specific to a particular supermarket chain. Generic brands have been in Australian supermarkets since the 1960s with an emphasis on lower prices and historically may have been lower-quality products ${ }^{(9)}$. Recently the two major Australian supermarket chains, who together have about $70 \%$ of the retail food market, have offered generic products across a greater number of categories and at different quality and pricing levels ${ }^{(9)}$.

Previous studies measuring the cost of food in Australia have generally focused on food cost, availability and quality for branded food products, and have not specifically examined these factors in relation to generic food brands ${ }^{(10-19)}$. However, one Australian study has shown that substituting generic brands for market brands reduced weekly food costs by about $13 \%{ }^{(20)}$. Two European studies reported that generic food product lines represent excellent value for money and were not nutritionally inferior to the equivalent branded products $^{(21,22)}$. These European findings, however, cannot be generalised to the retail context more broadly, such as in Australia. 
An Australian study that looked at over 3000 products found that food products manufactured on behalf of supermarket retailers and sold as generic private label products were not consistently nutritionally different from branded products, although there was some variability in the nutritional characteristics for some food categories ${ }^{(23)}$. That study also found that serving sizes varied between generic and branded food products for some food categories including pizza, canned legumes, ready meals, and savoury and sweet biscuits ${ }^{(23)}$.

Australian reports have found that more than $80 \%$ of consumers buy generic food products, despite a persistent perception that generic products are inferior to branded products ${ }^{(9)}$. The purpose of the present study was to compare the cost of popular branded food items with that of their generic equivalents to determine if the purchase of generic food products would lead to considerable cost savings for consumers.

\section{Methods}

\section{Survey tool}

Food items included in the study included 'core' foods ( $n$ 16) as outlined in the Australian Guide for Healthy Eating (Table 1$)^{(24)}$. Core food items were further classified into subcategories according to food groups comprising breads and cereals, vegetables, fruit, dairy foods and protein-rich foods. In addition, a sub-category of popular 'extra' foods ( $n$ ) that are also in the Consumer Price Index basket of foods was included to reflect the eating habits of the general population.

Food items were selected based on popularity as evidenced by their inclusion in the representative sample of foods used by the Australian Bureau of Statistics in determining the Consumer Price Index for Australia (L Taylor, personal communication, 2010). The products included in the Consumer Price Index pricing samples are selected carefully to represent the range of types and varieties of goods bought by the Consumer Price Index population group ${ }^{(25)}$. Selection is made after obtaining detailed information about the buying habits of the population group, such as which varieties and brands of products are the largest selling types or which packaging sizes are most commonly purchased ${ }^{(25)}$. This process involves extensive consultations with retailers and manufacturers. The reference population for the Australian Consumer Price Index is private households in the eight capital cities and represents about two-thirds of Australian private households ${ }^{(25)}$.

\section{Procedure}

The survey was conducted in six suburban locations across the Sydney metropolitan area with differing levels of socio-economic disadvantage, defined by the Australian Bureau of Statistics' Index of Relative Socio-economic Advantage and Disadvantage and classified into tertiles (most disadvantaged, moderately disadvantaged and least disadvantaged) ${ }^{(26)}$. The six locations included two suburbs from each socio-economic tertile.

Given the dominance of two major food retailers (referred to as Supermarket A and Supermarket B) in the Australian retail food sector $^{(9)}$, inclusion in the present study required that each suburb location contained both of the major supermarket chains. Locations were also required to be accessible by public transport. Both Supermarket A and Supermarket B have multiple 'tiers' of generic lines available for a range of products.

Data were collected by two student dietitians over a $3 \mathrm{~d}$ consecutive period in March 2009 on weekdays. The survey was initially piloted in two stores (not included in the final survey sample) to test the clarity of the instructions and reliability of the coding instrument. The survey tool was subsequently refined to improve its layout.

Surveyors recorded the standard shelf prices (not sale prices) for the specified pack size for the cheapest branded product and its generic equivalents in each supermarket. Prices for all available tiers of generic label ranges were recorded (e.g. savings and premium generic product lines).

\section{Inter-coder reliability}

Both coders independently surveyed four supermarkets and cross-checked their recorded prices. There was 90\% agreement between the coders, and discrepancies were discussed with the lead author to improve consistency. The remaining eight supermarkets were visited and surveyed individually by one of these two student dietitians.

\section{Data analysis}

Data were analysed using the SPSS for Windows statistical software package version $15 \cdot 0$ (SPSS Inc., Chicago, IL, USA). For a small number of items where the specified size was not available (due to the supermarket not having stock available for a particular product), the next nearest size was recorded and the price was adjusted to represent a standard unit price for between-product price comparisons. Percentage cost saving was calculated based on the difference in price between the cheapest branded item and the generic item, given as a proportion of the cheapest branded item.

Descriptive statistics were obtained for the cost of generic and branded food products for each selected food item. Differences in the cost of individual food items and the median cost of goods within a sub-category were analysed statistically using the Mann-Whitney test for non-parametric data.

\section{Results}

\section{Cost comparison between generic and branded food products}

The cheapest generic products were found to be lower in price than the cheapest branded products for all items 
Table 1 Cost comparison between the cheapest generic products and cheapest branded products by supermarket; survey conducted in two major supermarket chains across six locations in Sydney, Australia ( $n$ 12), March 2009

\begin{tabular}{|c|c|c|c|c|c|c|c|c|c|c|}
\hline \multirow[b]{3}{*}{ Food item } & \multicolumn{5}{|c|}{ Supermarket A } & \multicolumn{5}{|c|}{ Supermarket B } \\
\hline & \multicolumn{2}{|r|}{ Branded } & \multicolumn{2}{|r|}{ Generic } & \multirow[b]{2}{*}{$\begin{array}{c}\text { Cost } \\
\text { saving (\%) }\end{array}$} & \multicolumn{2}{|r|}{ Branded } & \multicolumn{2}{|r|}{ Generic } & \multirow[b]{2}{*}{$\begin{array}{c}\text { Cost } \\
\text { saving (\%) }\end{array}$} \\
\hline & $n$ & $\begin{array}{c}\text { Cheapest } \\
\text { price (\$AUD) }\end{array}$ & $n$ & $\begin{array}{c}\text { Cheapest } \\
\text { price (\$AUD) }\end{array}$ & & $n$ & $\begin{array}{c}\text { Cheapest } \\
\text { price (\$AUD) }\end{array}$ & $n$ & $\begin{array}{c}\text { Cheapest } \\
\text { price (\$AUD) }\end{array}$ & \\
\hline Traditional rolled oats & 6 & $3 \cdot 39$ & 12 & $1 \cdot 31$ & 61 & 6 & $3 \cdot 29$ & 11 & $1 \cdot 32$ & 60 \\
\hline Cornflakes & 6 & $3 \cdot 80$ & 6 & 1.99 & 48 & 6 & $2 \cdot 79$ & 12 & $2 \cdot 29$ & 18 \\
\hline Wholemeal bread & 6 & $3 \cdot 79$ & 11 & $1 \cdot 79$ & 53 & 6 & $3 \cdot 79$ & 14 & $2 \cdot 05$ & 46 \\
\hline White bread & 6 & $3 \cdot 79$ & 12 & 1.09 & 71 & 6 & $3 \cdot 79$ & 18 & 1.09 & 71 \\
\hline Breads \& Cereals total & 24 & $14 \cdot 77$ & 41 & $6 \cdot 18$ & 58 & 24 & $13 \cdot 66$ & 55 & $6 \cdot 75$ & 51 \\
\hline Diced canned tomatoes & 6 & $1 \cdot 25$ & 12 & $0 \cdot 75$ & 40 & 6 & $1 \cdot 29$ & 11 & 0.93 & 28 \\
\hline Canned baked beans in tomato sauce & 6 & $1 \cdot 29$ & 6 & 0.69 & 47 & 6 & $1 \cdot 30$ & 10 & 0.53 & 59 \\
\hline Frozen peas & 6 & $2 \cdot 90$ & 6 & 1.99 & 31 & 6 & $4 \cdot 06$ & 12 & 1.99 & 51 \\
\hline Vegetable \& Legumes total & 18 & $5 \cdot 44$ & 24 & $3 \cdot 43$ & 37 & 18 & $6 \cdot 65$ & 33 & $3 \cdot 45$ & 48 \\
\hline Canned peaches in juice & 6 & $3 \cdot 49$ & 6 & $2 \cdot 99$ & 14 & 6 & $3 \cdot 36$ & 6 & $2 \cdot 89$ & 14 \\
\hline Orange juice with no added sugar & 6 & $3 \cdot 19$ & 6 & $1 \cdot 89$ & 41 & 6 & $3 \cdot 19$ & 12 & $1 \cdot 89$ & 41 \\
\hline Fruit total & 12 & $6 \cdot 68$ & 12 & $4 \cdot 88$ & 27 & 12 & $6 \cdot 55$ & 18 & $4 \cdot 78$ & 27 \\
\hline Fresh full-cream milk & 6 & $3 \cdot 67$ & 12 & $2 \cdot 17$ & 41 & 6 & $3 \cdot 76$ & 12 & $2 \cdot 10$ & 44 \\
\hline Fresh low-fat milk & 6 & $4 \cdot 63$ & 6 & $2 \cdot 57$ & 44 & 6 & $4 \cdot 63$ & 9 & $2 \cdot 44$ & 47 \\
\hline Full-fat cheddar cheese & 6 & $6 \cdot 89$ & 12 & $3 \cdot 79$ & 45 & 6 & $6 \cdot 89$ & 12 & $3 \cdot 79$ & 45 \\
\hline Low-fat cheddar cheese & 6 & $6 \cdot 89$ & 5 & 3.99 & 42 & 6 & $5 \cdot 86$ & 6 & $6 \cdot 49$ & -11 \\
\hline Dairy total & 24 & $22 \cdot 08$ & 35 & $12 \cdot 52$ & 43 & 24 & $21 \cdot 14$ & 39 & $14 \cdot 82$ & 30 \\
\hline Canned tuna in spring water & 6 & $1 \cdot 71$ & 12 & 0.95 & 44 & 6 & $1 \cdot 79$ & 6 & $1 \cdot 59$ & 11 \\
\hline Cage eggs & 6 & $4 \cdot 38$ & 12 & $2 \cdot 69$ & 39 & 6 & $4 \cdot 60$ & 12 & $2 \cdot 69$ & 42 \\
\hline Smooth peanut butter & 6 & $2 \cdot 63$ & 12 & $2 \cdot 10$ & 20 & 6 & $2 \cdot 99$ & 11 & $2 \cdot 11$ & 29 \\
\hline Protein Foods total & 18 & $8 \cdot 72$ & 36 & $5 \cdot 74$ & 34 & 18 & $9 \cdot 38$ & 29 & $6 \cdot 39$ & 32 \\
\hline Choc chip biscuits & 6 & $4 \cdot 78$ & 12 & $2 \cdot 09$ & 56 & 6 & $4 \cdot 78$ & 6 & $2 \cdot 09$ & 56 \\
\hline Choc chip chewy muesli bar & 6 & 3.99 & 6 & $1 \cdot 64$ & 59 & 6 & 3.99 & 12 & $1 \cdot 74$ & 56 \\
\hline Canola margarine & 6 & $3 \cdot 26$ & 6 & $1 \cdot 29$ & 60 & 6 & 1.99 & 11 & 1.09 & 45 \\
\hline Frozen oven baked chips straight cut & 6 & $3 \cdot 38$ & 10 & 1.99 & 41 & 6 & $3 \cdot 48$ & 12 & 1.99 & 43 \\
\hline Fish fingers & 6 & $4 \cdot 99$ & 5 & $1 \cdot 80$ & 64 & 6 & $4 \cdot 49$ & 12 & $1 \cdot 68$ & 63 \\
\hline Regular cola & 6 & $1 \cdot 31$ & 6 & $1 \cdot 19$ & 9 & 6 & $1 \cdot 48$ & 10 & 0.99 & 33 \\
\hline Extra Foods total & 36 & $21 \cdot 71$ & 45 & $10 \cdot 00$ & 54 & 36 & $20 \cdot 21$ & 63 & $9 \cdot 58$ & 53 \\
\hline Total food product sample & 132 & $79 \cdot 40$ & 193 & $42 \cdot 75$ & 46 & 132 & $77 \cdot 59$ & 237 & $45 \cdot 77$ & 41 \\
\hline
\end{tabular}

and in both supermarkets, except for low-fat cheddar cheese in Supermarket B (Table 1).

Purchasing generic equivalents rather than branded items was found to provide a mean cost saving of $44 \%$ across all food categories. Greatest cost savings were found in the bread and cereals sub-category, where savings of $60 \%$ or more were found for rolled oats (60\%) and white bread $(71 \%)$. The smallest cost saving was reported in the fruit sub-category $(27 \%)$.

The mean percentage cost saving was calculated across all food groups by socio-economic status tertile, by using the cheapest available product from both generic and branded categories. There was little variation in cost savings across the socio-economic tertiles, ranging from $42 \%$ in the least disadvantaged areas to $43 \%$ in the most disadvantaged areas.

The mean saving obtained from purchasing the cheapest generic products over branded products was $46 \%$ at Supermarket A and $41 \%$ at Supermarket B (Table 1). The cost saving between generic and branded items was the same (27\% mean cost saving) at both supermarket chains for the fruit category, whereas for all other food categories there were different levels of cost savings between the two supermarket chains (Fig. 1). The greatest difference in the mean cost saving between Supermarket A and B was reported for the dairy product category where a $13 \%$ difference in cost was found.

The median cost of all tiers of generic items was significantly lower than the branded equivalent (Fig. 2). This was true for all items except for rolled oats, canned tomatoes, peanut butter, choc chip biscuits and regular cola (Table 2). Comparing only the cheapest available tier of generic products, the median cost was significantly lower than the branded equivalent for all items $(P=0 \cdot 001$ for regular cola, all others $P<0 \cdot 001$; data not shown).

\section{Discussion}

The present study highlighted that significant cost savings can be made by purchasing generic food products, particularly for core foods such as bread and cereals, where savings were as high as $53 \%$ for wholemeal bread and $46 \%$ overall for the breads and cereals sub-category. 


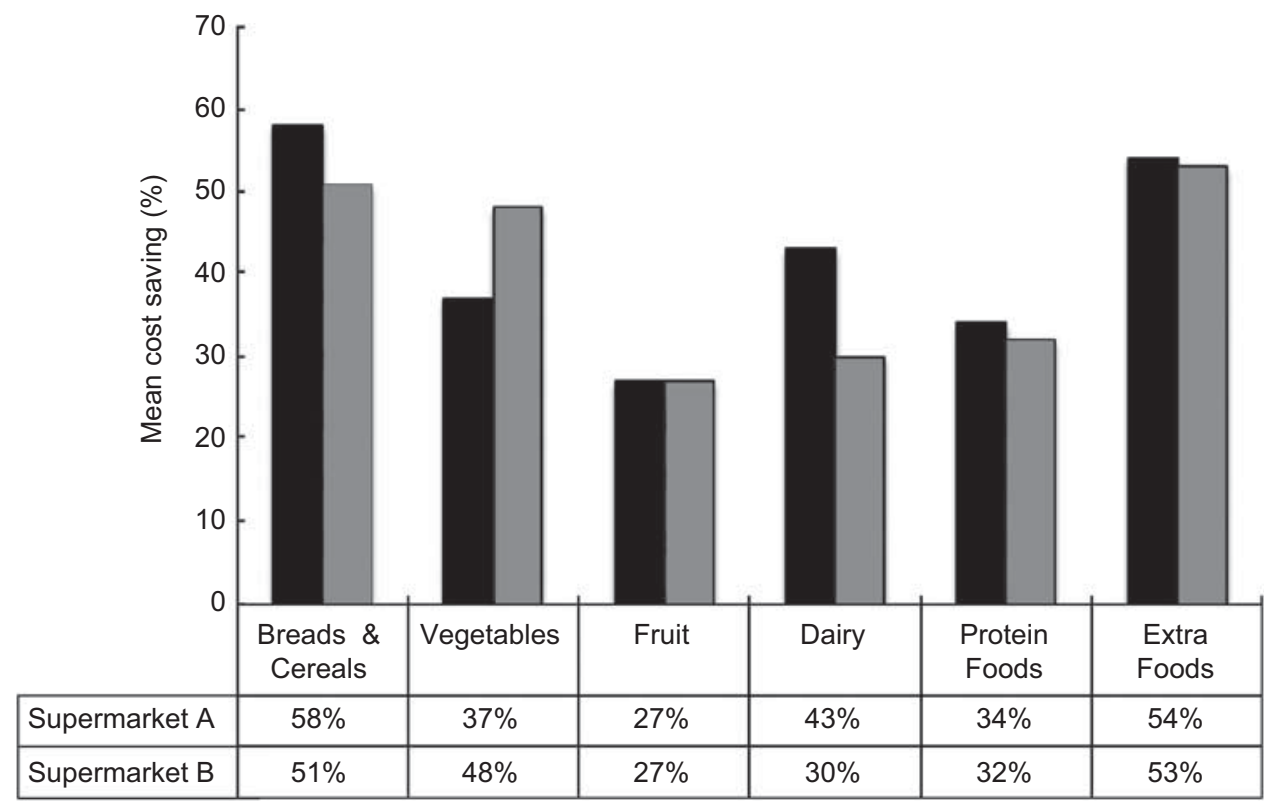

Fig. 1 Mean percentage cost saving between cheapest generic and cheapest branded product for Supermarket $A$ ( $\square$ ) and Supermarket B $(\square)$ by food category; survey conducted in two major supermarket chains across six locations in Sydney, Australia (n 12), March 2009

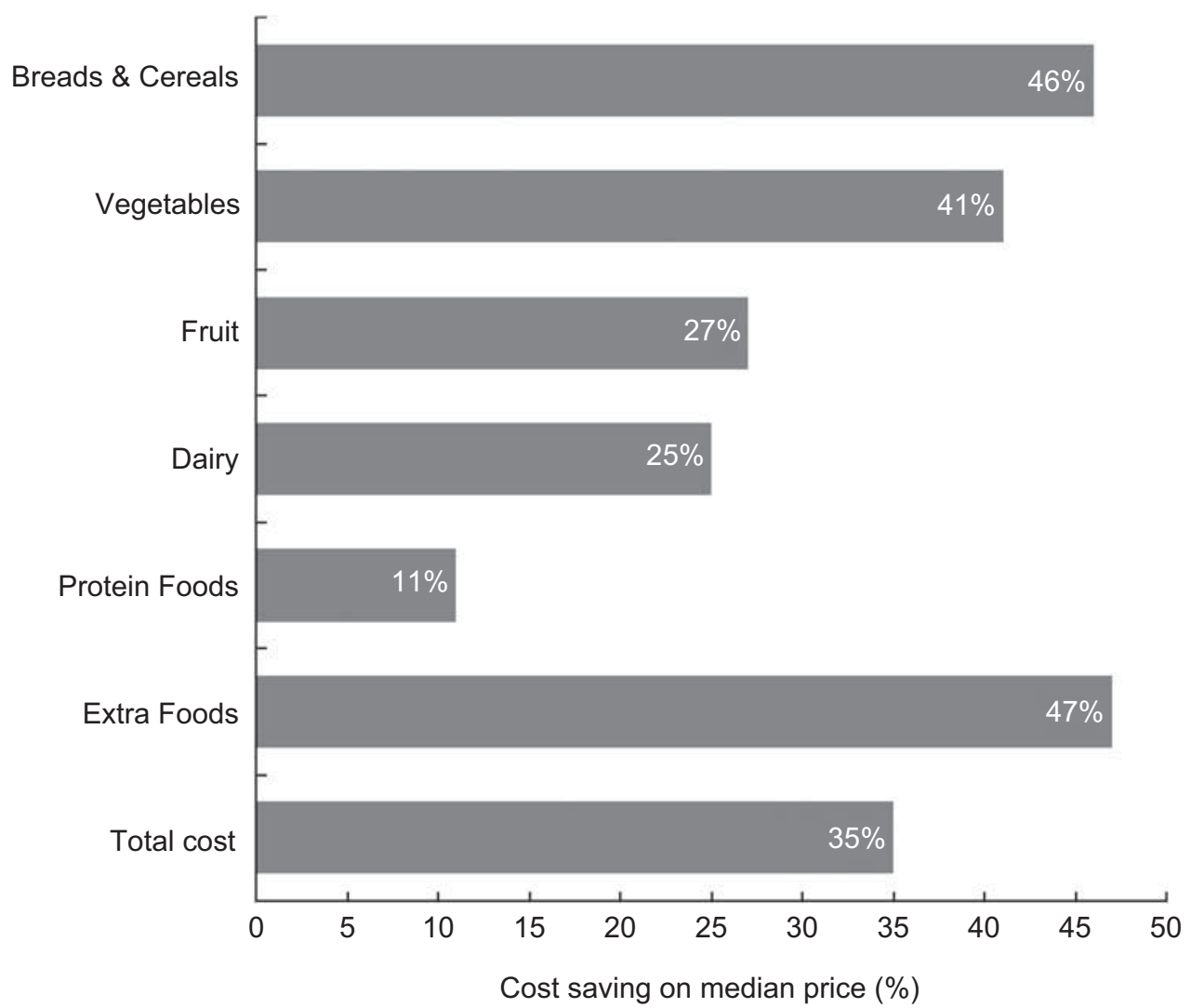

Fig. 2 Percentage cost saving on median price between generic products and branded products by food category; survey conducted in two major supermarket chains across six locations in Sydney, Australia (n 12), March 2009

Given that the Australian Guide to Healthy Eating recommends up to 12 servings of bread and cereals daily for an adult person ${ }^{(24)}$, this has the potential to save costs in the food budget for both families and individuals. The only previous Australian study to examine substitution of generic brands for branded products showed a $13 \%$ 
Table 2 Difference in median of cost of branded and generic food items; survey conducted in two major supermarket chains across six locations in Sydney, Australia ( $n$ 12), March 2009

\begin{tabular}{|c|c|c|c|c|c|c|}
\hline \multirow[b]{2}{*}{ Food item } & \multicolumn{2}{|r|}{ Branded } & \multicolumn{2}{|r|}{ Generic } & \multirow{2}{*}{$\begin{array}{c}\text { Cost } \\
\text { saving (\%) }\end{array}$} & \multirow{2}{*}{$\begin{array}{c}\text { Mann-Whitney } \\
\text { test } P \text { value }\end{array}$} \\
\hline & $n$ & Median price (\$AUD) & $n$ & Median price (\$AUD) & & \\
\hline Traditional rolled oats & 12 & $3 \cdot 34$ & 23 & $1 \cdot 33$ & 60 & 0.85 \\
\hline Cornflakes & 12 & $3 \cdot 80$ & 18 & $2 \cdot 29$ & 40 & $<0.001$ \\
\hline Wholemeal bread & 12 & $3 \cdot 79$ & 25 & $2 \cdot 28$ & 40 & $<0.001$ \\
\hline White bread & 12 & $3 \cdot 79$ & 30 & $2 \cdot 05$ & 46 & $<0.001$ \\
\hline Breads \& Cereals total & 48 & $14 \cdot 72$ & 96 & $7 \cdot 95$ & 46 & \\
\hline Diced canned tomatoes & 12 & $1 \cdot 27$ & 23 & $1 \cdot 19$ & 6 & 0.09 \\
\hline Canned baked beans in tomato sauce & 12 & $1 \cdot 30$ & 16 & 0.69 & 47 & $<0.001$ \\
\hline Frozen peas & 12 & $4 \cdot 03$ & 18 & $1 \cdot 99$ & 51 & $<0.001$ \\
\hline Vegetable \& Legumes total & 36 & $6 \cdot 60$ & 57 & $3 \cdot 87$ & 41 & \\
\hline Canned peaches in juice & 12 & $3 \cdot 43$ & 12 & $2 \cdot 94$ & 14 & $<0.001$ \\
\hline Orange juice with no added sugar & 12 & $3 \cdot 19$ & 18 & $1 \cdot 89$ & 41 & $<0.001$ \\
\hline Fruit total & 24 & $6 \cdot 62$ & 30 & $4 \cdot 83$ & 27 & \\
\hline Fresh full-cream milk & 12 & $3 \cdot 76$ & 24 & $2 \cdot 32$ & 38 & $<0.001$ \\
\hline Fresh low-fat milk & 12 & $4 \cdot 63$ & 15 & $2 \cdot 57$ & 44 & $<0.001$ \\
\hline Full-fat cheddar cheese & 12 & $6 \cdot 89$ & 24 & $5 \cdot 24$ & 24 & $<0.001$ \\
\hline Low-fat cheddar cheese & 12 & $6 \cdot 89$ & 11 & $6 \cdot 49$ & 6 & $<0.001$ \\
\hline Dairy total & 48 & $22 \cdot 17$ & 74 & $16 \cdot 62$ & 25 & \\
\hline Canned tuna in spring water & 12 & $1 \cdot 75$ & 18 & 1.59 & 9 & $<0.001$ \\
\hline Cage eggs & 12 & $4 \cdot 49$ & 24 & $3 \cdot 34$ & 26 & 0.005 \\
\hline Smooth peanut butter & 12 & $2 \cdot 81$ & 23 & $3 \cdot 14$ & -12 & 0.85 \\
\hline Protein Foods total & 36 & $9 \cdot 05$ & 65 & $8 \cdot 07$ & 11 & \\
\hline Choc chip biscuits & 12 & $4 \cdot 78$ & 18 & $2 \cdot 09$ & 56 & $0 \cdot 13$ \\
\hline Choc chip chewy muesli bar & 12 & 3.99 & 18 & $1 \cdot 74$ & 56 & $<0.001$ \\
\hline Canola margarine & 12 & $2 \cdot 64$ & 17 & $1 \cdot 29$ & 51 & $<0.001$ \\
\hline Frozen oven baked chips straight cut & 12 & $3 \cdot 43$ & 22 & $1 \cdot 99$ & 42 & $<0.001$ \\
\hline Fish fingers & 12 & 4.99 & 17 & $2 \cdot 99$ & 40 & $<0.001$ \\
\hline Regular cola & 12 & $1 \cdot 50$ & 16 & $1 \cdot 19$ & 21 & $0 \cdot 31$ \\
\hline Extra Foods total & 72 & $21 \cdot 33$ & 108 & $11 \cdot 29$ & 47 & \\
\hline Total cost of all food products & 264 & $80 \cdot 49$ & 430 & $52 \cdot 63$ & 35 & \\
\hline
\end{tabular}

Note: the Mann-Whitney test ranked multiple tiers of generic items in the analysis, leading to a bi-modal distribution of generic prices.

reduction in weekly food costs, based on dietary modelling of a $7 \mathrm{~d}$ meal plan for two typical welfare-dependent Australian families ${ }^{(20)}$.

Previous studies have found that low-income groups are least likely to purchase foods that are consistent with dietary guidelines ${ }^{(17,27,28)}$. In particular, those in low socio-economic groups are less likely to purchase foods that are high in fibre and low in fat, sugar and salt, and the consumption of fruit and vegetables in this group is likely to be lower ${ }^{(17,27,29)}$. Consumers with lower household incomes also have a higher tendency to purchase generic products $^{(30)}$, making the nutritional adequacy of these products an issue of public health interest.

In a report on the competitiveness of retail prices of grocery items, the Australian statutory agency responsible for fair trade and competition, the Australian Competition and Consumer Commission (ACCC), concluded that pricing strategies adopted by the major supermarket chains for their premium generic label products result in those generic products generally having lower shelf prices than branded products of comparable quality ${ }^{(9)}$. According to the ACCC's consumer survey, although most consumers buy some generic products, there is a persistent perception that generic equivalents are of inferior quality to branded products $^{(9)}$. However, the ACCC found that if consumers considered a generic product to be a close substitute for the targeted branded product, they were more likely to switch to that generic brand in response to its lower price ${ }^{(9)}$. In a blinded study comparing the taste of generic and branded food items by the Australian consumer group CHOICE, consumers rated 'premium' (i.e. top tier) generic foods as equivalent to or better than the leading brands for taste ${ }^{(31)}$.

Consumer purchases are not, however, solely driven by price or nutrition ${ }^{(32)}$. Country of origin is an emerging issue for some consumers who are concerned about 'food miles' and the carbon emissions associated with food distribution from 'paddock to plate ${ }^{\text {(33) }}$. In 2006, CHOICE reported that fewer generic products are Australian made and owned ${ }^{(31)}$. The present study found that Australian products were available in generic lines for most food categories in the survey (data not shown). Further work on the role of generic foods should include providing consumers with information on cost-competitive, nutritious and environmentally sustainable food.

There has been criticism of the large supermarket chains for introducing greater numbers of generic products 
as this has the potential to limit consumer choices and negatively impact on smaller suppliers, primary producers and farmers ${ }^{(34)}$. Some commentators believe less choice may mean less innovation and fewer new products introduced into the market, and although there may be short-term price cuts, it may result in higher costs in the longer term. However, a recent Australian Senate inquiry about the impacts on the dairy industry of supermarket price cutting on milk found that milk price discounting is likely to be pro-competitive and of benefit to consumers; although the report did note that there were some instances whereby the risk of any retail price movements or other shocks that affect the sales of branded products were in large part being passed immediately onto the dairy farmers ${ }^{(35)}$.

Supermarket chains argue that cost savings on generic lines are primarily achieved by reducing marketing costs and by controlling the production networks, not by using low-grade ingredients ${ }^{(9)}$. Leading brands often attribute their product's expense to the use of highest-quality ingredients. However for processed food products, standardisation of ingredients and control of processing are likely to be high, resulting in less difference nutritionally between products of the same food item ${ }^{(21)}$. An Australian study has confirmed that generally generic food products were nutritionally similar to branded products ${ }^{(23)}$, which is a positive finding for consumers, especially those on low incomes.

The current study has some limitations. First, a limited number of food products ( $n$ 22) were surveyed from the two major supermarket chains. However, the foods selected in the sample are included among the popular foods analysed for the Australian Consumer Price Index and were a more expansive range of foods than those analysed in previous studies of generic food prices ${ }^{(21,22)}$. Second, while the two supermarket chains surveyed account for $70 \%$ of packaged grocery sales ${ }^{(9)}$, consumers also purchase foods at other retail outlets. Third, the study looked only at the regular price of products, rather than the sale price. The purchase of items on special offer may result in further cost savings. The study compared the generic items with the cheapest branded products available at the time of survey. Even greater price differences would have been found in comparison with more expensive branded products. Finally, a further limitation of the study was that price information was collected for specified pack sizes, and this may not reflect the cost savings experienced by those consumers who buy larger bulk-sized products or the differences in those who rely on smaller convenience-sized products.

Financial constraints are potentially the largest contributor to food insecurity faced by low-income families ${ }^{(28)}$. Low-income groups have been shown to be least likely to purchase foods that are consistent with the recommendations in dietary guidelines ${ }^{(17,27,28)}$. The significant price differential between branded items and their generic equivalents implies that consumers, particularly those on lower incomes, could benefit financially from purchasing generic lines without compromising the quality of their diets. Further research on the nutritional quality of generic food products and how they compare with branded products would be valuable given the cost benefits of selecting generic products. In addition, research on the purchasing patterns of low-income consumers would be beneficial to determine whether those who purchase generic products do so across a range of food product types or a more narrow range of food product types.

The promotion of generic lines, particularly for core foods such as breads and cereals, dairy foods, protein foods, and canned and frozen fruits and vegetables, may be an effective strategy to assist people on lower incomes to meet dietary guidelines, which are protective against chronic disease. This strategy may have greatest impact when incorporated into healthy food budgeting programmes targeting people at socio-economic disadvantage.

\section{Acknowledgements}

This work was supported by Cancer Council NSW. The authors declare no conflicts of interest. The authors' contributions were as follows: K.C., study design, supervision of data collection, interpretation of results, drafting of paper; C.I.-H., data analysis, initial drafting of paper; D.G., data analysis and statistical advice, contribution to paper; B.K., input into study design and implementation, contribution to paper; A.B., interpretation of results, reviewing of paper; M.A.-F., interpretation of results, reviewing of paper. The authors wish to thank Laura Owens and Joyi Shi, Master of Nutrition and Dietetics students from the University of Sydney, for their contribution to the survey and data analysis.

\section{References}

1. Andrieu E, Darmon N \& Drewnowski A (2006) Low-cost diets: more energy, fewer nutrients. Eur J Clin Nutr 60, 434-436.

2. World Health Organization (2003) Diet, Nutrition and the Prevention of Chronic Diseases. Report of a Joint WHO/FAO Expert Consultation. WHO Technical Report Series no. 916. Geneva: WHO.

3. Australian Bureau of Statistics (2011) Consumer Price Index 2011, March 2011. Canberra: ABS.

4. Drewnowski A \& Darmon N (2005) The economics of obesity: dietary energy density and energy cost. Am J Clin Nutr 82, 1 Suppl., 265S-273S.

5. Lennernas M, Fjellstrom C, Becker W et al. (1997) Influences on food choice perceived to be important by nationally-representative samples of adults in the European Union. Eur J Clin Nutr 51, Suppl. 2, S8-S15.

6. Lee J, Ralston R \& Truby H (2011) Influence of food cost on diet quality and risk factors for chronic disease: a systematic review. Nutr Diet 68, 248-261.

7. Ni Mhurchu C \& Ogra S (2007) The price of healthy eating: cost and nutrient value of selected regular and healthier supermarket foods in New Zealand. NZ Med J 120, U2388. 
8. Andreyeva T, Blumenthal DM, Schwartz MB et al. (2008) Availability and prices of foods across stores and neighborhoods: the case of New Haven, Connecticut. Health Aff (Millwood) 27, 1381-1388.

9. Australian Competition and Consumer Commission (2008) Report of the ACCC Inquiry into the Competitiveness of Retail Prices for Standard Groceries. Canberra: ACCC.

10. Burns C \& Friel S (2007) It's time to determine the cost of a healthy diet in Australia. Aust $N Z J$ Public Health 31, 363-365.

11. Burns C, Gibbon P, Boak R et al. (2004) Food cost and availability in a rural setting in Australia. Rural Remote Health 4, 311.

12. Harrison MS, Coyne T, Lee AJ et al. (2007) The increasing cost of the basic foods required to promote health in Queensland. Med J Aust 186, 9-14.

13. Lee AJ, Darcy AM, Leonard D et al. (2002) Food availability, cost disparity and improvement in relation to accessibility and remoteness in Queensland. Aust $N Z J$ Public Health 26, 266-272.

14. Meedeniya J, Smith A \& Carter P (2000) Food supply in rural South Australia: a survey on food cost, quality and variety. http://www.chdf.org.au/cgi-bin/displayfile?page $=/$ 1/128/FoodSupplyReportBW.PDF (accessed September 2006).

15. Palermo CE, Walker KZ, Hill P et al. (2008) The cost of healthy food in rural Victoria. Rural Remote Health 8, 1074.

16. Tsang A, Ndung'U M, Coveney J et al. (2007) Adelaide healthy food basket: a survey on food cost, availability and affordability in five local government areas in metropolitan Adelaide, South Australia. Nutr Diet 64, 241-247.

17. Turrell G, Hewitt B, Patterson C et al. (2002) Socioeconomic differences in food purchasing behaviour and suggested implications for diet-related health promotion. J Hum Nutr Diet 15, 355-364.

18. Williams P, Hull A \& Kontos M (2009) Trends in affordability of the Illawarra Healthy Food Basket 2000-2007. Nutr Diet 66, 27-32.

19. Cancer Council NSW (2007) NSW Healthy Food Basket Cost, Availability and Quality Survey. Sydney: Cancer Council NSW.

20. Kettings C, Sinclair AJ \& Voevodin M (2009) A healthy diet consistent with Australian health recommendations is too expensive for welfare-dependent families. Aust N ZJ Public Health 33, 566-572.

21. Cooper S \& Nelson M (2003) 'Economy' line foods from four supermarkets and brand name equivalents: a comparison of their nutrient contents and costs. J Hum Nutr Diet 16, 339-347.
22. Darmon N, Caillavet F, Joly C et al. (2009) Low-cost foods: how do they compare with their brand name equivalents? A French study. Public Health Nutr 12, 808-815.

23. Cleanthous X, Mackintosh A-M \& Anderson S (2011) Comparison of reported nutrients and serve size between private label products and branded products in Australian supermarkets. Nutr Diet 68, 120-126.

24. Australian Government \& Department of Health and Ageing (1998) Australian Guide to Healthy Eating. Canberra: Commonwealth of Australia.

25. Australian Bureau of Statistics (2011) Consumer Price Index: Concepts, Sources and Methods. Canberra: ABS.

26. Australian Bureau of Statistics (2007) Census of Population and Housing: Socio-Economic Indexes for Areas (SEIFA), Australia - Data Cube only, 2001. http://www.abs.gov.au/ Ausstats/abs@.nsf/7d12b0f6763c78caca257061001cc588/ 8298f6ab51491a7cca2570a400770380\%21OpenDocument (accessed March 2007).

27. Giskes K, Turrell G, Patterson C et al. (2002) Socioeconomic differences in fruit and vegetable consumption among Australian adolescents and adults. Public Health Nutr 5, 663-669.

28. Turrell G (1998) Socioeconomic differences in food preference and their influence on healthy food purchasing choices. J Hum Nutr Diet 11, 135-149.

29. Yeh MC, Ickes SB, Lowenstein LM et al. (2008) Understanding barriers and facilitators of fruit and vegetable consumption among a diverse multi-ethnic population in the USA. Health Promot Int 23, 42-51.

30. Prendergast G \& Marr N (1997) Generic products: who buys them and how do they perform relative to each other? Eur J Mark 31, 94-109.

31. CHOICE (2006) Supermarket brands. http://www.choice. com.au (accessed March 2009).

32. Shepherd R \& Raats M (2006) The Psychology of Food Choice. Cambridge, MA: CAB International.

33. Blewett N, Goddard N, Pettigrew S et al. (2011) 'Labelling Logic' - The Final Report of the Review of Food Labelling Law and Policy. http://www.foodlabellingreview.gov.au/ internet/foodlabelling/publishing.nsf/content/labelling-logic (accessed August 2011).

34. Cowie T (2011) Stacking the shelves: the home brand backlash, from pollies to rivals. Crikey, 30 March; available at http://www.crikey.com.au/2011/03/30/stacking-theshelves-the-home-brand-backlash-from-pollies-to-competitors

35. Senate Economics Reference Committee (2011) The Impact of Supermarket Price Decisions on the Dairy Industry: Final Report. Canberra: Australian Government. 